\title{
Water extraction by tree fine roots in the forest floor of a temperate Fagus-Quercus forest
}

\author{
Christoph Leuschner* \\ Plant Ecology, FB 19, University of Kassel, Heinrich-Plett-Str. 40, 34132 Kassel, Germany
}

(Received 15 January 1997; accepted 19 June 1997)

\begin{abstract}
Water retention and water turnover were investigated in the forest floor of a temperate mixed Fagus-Quercus forest on poor soil in NW Germany. By field and laboratory measurements the aim was to quantify the water extraction by those tree fine roots that concentrate in the superficial organic layers. The 8-10.5-cm-thick organic profiles stored up to $45 \mathrm{~mm}$ of water under Quercus trees but significantly smaller amounts under Fagus (and even less under Pinus trees in a nearby stand). The water retention capacity (i.e. the difference between saturating water content after wetting and water content prior to wetting) and the resulting percolation rate out of the forest floor were measured by infiltration experiments in relation to their dependence on the initial water content of the humus material. The water retention characteristics of the humus material differed from the sandy mineral soil material by i) a much higher maximum water content (porosity), ii) a higher storage capacity for water in the plant-available water potential range, and iii) a marked temporal variability of the water retention capacity. A one-dimensional water flux model for the forest floor of this stand has been developed. According to the model results, the forest floor contributed $27 \%$ (in summer 1991) or $14 \%$ (in summer 1992) to the stand soil water reserves, and $37 \%$ (summer 1991) or $28 \%$ (summer 1992) to the water consumption of this stand. Water was turned over in the forest floor twice as fast as in the underlying mineral soil; however, fine roots in the mineral soil apparently extract more water per standing crop of root biomass and, thus, are thought to operate more economically with respect to the carbon cost of water uptake. (@ Inra/Elsevier, Paris.)
\end{abstract}

Fagus sylvatica / fine roots / forest floor / deciduous forest / water content / water extraction

Résumé - Extraction de l'eau par les racines fines dans les horizons superficiels du sol d'une forêt tempérée de chênes et de hêtres. La capacité de rétention et les flux d'eau ont été analysés dans les horizons superficiels organiques du sol d'une forêt mélangée de chênes et de hêtres, sur un site pauvre du nord-ouest de l'Allemagne. L'objectif de ce travail était de quantifier l'extraction de l'eau dans le sol par les fines racines des horizons superficiels riches en matière organique. La capacité de stockage en eau de la tranche superficielle de 8 à $10,5 \mathrm{~cm}$ d'épaisseur attei-

* Correspondence and reprints

Tel: (49) 5618044364; fax: (49) 5618044115; e-mail: leuschne@hrz.uni-kassel.de 
gnait $45 \mathrm{~mm}$ d'eau sous les chênes, mais était significativement plus faible sous les hêtres, et encore plus faible sous une pinède proche. La capacité de rétention en eau (calculée par la différence d'humidité entre la capacité de saturation avant et après humectation), ainsi que le taux de percolation sous l'horizon organique ont été mesurés par infiltration expérimentale, et mis en relation avec la teneur en eau initiale de l'humus. Les caractéristiques de rétention en eau de l'humus montrent des différences par rapport à un sol minéral de type sableux par a) une teneur en eau maximale très supérieure, liée à la porosité, b) une plus grande capacité de stockage de l'eau dans la gamme des potentiels hydriques utilisables par les arbres, et c) une forte variabilité temporelle de la capacité de rétention. Un modèle monodimentionnel de transfert d'eau dans les horizons de surface a été développé pour le peuplement étudié. Selon les simulations, la contribution de la couche organique assurait $27 \%$ (en été 1991), ou $14 \%$ (en été 1992) de la réserve en eau totale du sol, et $37 \%$ (été 1991), ou $28 \%$ (été 1992) de la consommation en eau du peuplement. Le renouvellement de l'eau dans la tranche superficielle était deux fois plus rapide que dans les horizons minéraux sous-jacents. Toutefois, le taux d'extraction d'eau par les racines fines était plus important par unité de biomasse racinaire dans les horizons minéraux ; de ce fait, ces racines ont montré un fonctionnement plus économique en terme de coût en carbone. (@ Inra/Elsevier, Paris.)

\section{Fagus sylvatica / racines fines / litière / forêt feuillue / teneur en eau / extraction d'eau}

\section{INTRODUCTION}

Forest ecosystems on nutrient-poor acidic soils are characterized by thick organic layers at the forest floor which play a key role in the nutrient cycles of these systems $[6,13]$. For various temperate and tropical forests on poor substrates, the organic profile has been identified as the main source of nutrient supply that contains high densities of tree fine roots $[12,17,19]$. Much less attention has been paid to the moisture regime of the organic profile although much of the biological activity in the forest floor depends on the moisture status of this medium [23, 25]. Furthermore, water infiltrating into the soil first passes through this uppermost horizon where it meets a high density of tree fine roots, mycorrhizal hyphae and microorganisms [3]. Thus, a rapid uptake of water by superficial roots in the forest floor could represent a crucial advantage for plants that compete for water [21].

Research in forest floor hydrology has been conducted predominantly by foresters who were interested in erosion control or wished to predict the threat by ground fires as a function of the forest floor water con- tent (e.g. $[2,4,8,16])$. Organic material at various stages of decomposition represents a unique medium that retains and also conducts water in a rather different manner when compared to the mineral soil matrix $[9,16]$. Hydrologists concerned with the soil-vegetation-atmosphere transfer of water (SVAT) only recently paid attention to the fact that the water flux in many forest ecosystems on poor soils cannot be described accurately as long as the organic profile is ignored in the models or treated in analogy to the mineral soil [20].

This study investigates availability and turnover of water in the forest floor of a deciduous two-species (Fagus-Quercus) forest stand in NW Germany in its relation to tree fine root distribution. The main questions were:

1) Does the forest floor significantly contribute to the root water uptake of the trees?

2) Is the type of litter (or the tree species) an influential factor in the forest floor hydrology?

3) What relation exists between fine root abundance and water extraction in forest floor and mineral soil profile? 
The study is part of a comparative analysis of the water and nutrient cycles in three forest and heathland stands that represent early, mid and late stages of a secondary succession (cf. $[12,18]$ ). Other research activities concentrated on the water flux in the mineral soil, the overstorey evapotranspiration (Leuschner, in prep.), and the distribution and turnover of fine roots ([3]; Hertel, in prep.).

\section{MATERIALS AND METHODS}

\subsection{Study site}

The investigations were carried out from 1991 to 1993 in an old-growth mixed Fagus sylvatica L.-Quercus petraea Matt. (Liebl.) forest on poor sandy soil in the diluvial lowlands of NW Germany (site OB5). The stand is located west of Unterlüss in the southeastern part of the Lüneburger Heide $\left(52^{\circ} 45^{\prime} \mathrm{N}, 10^{\circ} 30^{\prime}\right.$ $\mathrm{E}$ ) in level terrain and stocks on fluvio-glacial sandy deposits (predominantly medium-grained sand) of the penultimate (Saale) Ice Age with a low silicate content and a high soil acidity [ $\mathrm{pH}$ values (in $1 \mathrm{M} \mathrm{KCl}$ ) of the topsoil: $2.6-2.8]$. The ground water table is far beyound the rooting horizon. The soil type is a spodo-dystric cambisol; the 8-10.5-cm-deep forest floor is built by a three-layered ( $\mathrm{L}, \mathrm{F}, \mathrm{H}$ horizons) Mor-type organic profile (mainly Hemimors and Hemihumimors according to the classification of Klinka et al. [10]; cf. [11]). The profile is significantly thicker in the direct vicinity of oak stems than at beech stems (Leuschner, unpubl.). Ninety percent of the stems are beeches (age: $90-110$ years), $10 \%$ are oaks (180-200 years). A herbaceous layer is lacking. The climate is of a temperate suboceanic type (annual precipitation ca $730 \mathrm{~mm}$, mean air temperature $8.0^{\circ} \mathrm{C}$ ).

For comparison, several analyses were also conducted in a 30-year-old 12-m high pine-birch (Pinus sylvestris L., Betula pendula Roth) stand in the vicinity (site BP3, with pine dominance). On similar geological substrate, an iron-humus podzol with a $8-9 \mathrm{~cm}$ thick Mor profile (Hemimors, Hemihumimors and Xeromors) is present here.

\subsection{Hydrological measurements}

The basic method to monitor the water content of the forest floor $\theta$ was a sequential coring technique with gravimetric determination of the water content in the $\mathrm{O}_{\mathrm{F}}$ and $\mathrm{O}_{\mathrm{H}}$ layers. Representative plots with predominant oaks or beeches (or pine at site BP3) were separately sampled. From May 1991 until December 1992, eight samples each per tree species were taken weekly (in summer) or 2-4 weekly (in winter) with a 5 -cm-diameter root corer systematically at a distance of $40-200 \mathrm{~cm}$ from a stem. By simultaneous measurement of the profile depth in undisturbed samples, the water content data could be expressed as volume percent $\left(\right.$ vol. \%) or fractional water content $\left(\mathrm{cm}^{3}\right.$ $\mathrm{cm}^{-3}$ ) and also in terms of water storage (in $\mathrm{mm}$ per profile). The spatial variability of $\theta$ in the forest floor is characterized by an annual mean coefficient of variance of the moisture samples of 14.2, 15.8 and $23.4 \%$ at the beech, oak and pine sites, respectively. The water content of the mineral soil profile was monitored fortnightly by TDR technique and by gravimetric determination until a depth of $70 \mathrm{~cm}$.

Water retention curves (i.e. the relationship between soil water matric potential $\Psi_{\mathrm{m}}$ and volumetric water content $\theta$ ) were measured at 'undisturbed' samples of $250 \mathrm{~cm}^{3}$ volume from the organic $\mathrm{O}_{\mathrm{FH}}$ layers by desorption with hanging water columns in the laboratory. Five samples each from oak and beech (site OB5) and pine (site BP3) humus were analysed. For comparison, sandy material of the uppermost $A_{h}$ horizon was also investigated. Water held at matric potentials $<-1.5 \mathrm{MPa}$ was termed 'nonroot-extractable', water held between $-100 \mathrm{hPa}$ and $-1.5 \mathrm{MPa}$ was considered as 'plant-available'. The water content directly after a saturating infiltration is taken as the "saturated water content' $\theta_{\mathrm{s}}$ of the humus material. This is lower than the maximum water content $\theta_{\max }$ (= porosity) of the organic material with all air space filled with water.

Laboratory infiltration experiments were conducted to establish relationships between rainfall amount, water retention of the humus material (wetting curves) and resulting percolation loss out of the forest floor. Undisturbed forest floor sods of $17 \times 37 \mathrm{~cm}$ size (sampled under beech) were treated with $0.5-30 \mathrm{~mm}$ of artificial rain. The sod weight was determined 5 min after application and the retained and the percolated water were expressed as a func- 
tion of rainfall and initial humus water content. This procedure was repeated with sods of varying moisture content $(10-31.5 \mathrm{~mm}$ initial water storage). Each treatment was conducted with five replicates that were averaged.

In order to quantify the water turnover of the organic profile it was attempted to measure the relevant water fluxes directly in the field with appropriate techniques and to describe the water flux with a one-dimensional model (forest floor water flux model) in temporal resolution of one day. Details on the flux measurements and the model will be published elsewhere (Leuschner, in prep.). Here, only a short overview on the methods and the basic philosophy of the model are presented. Water input to the forest floor is generated by canopy throughfall (TF) and, locally, by stemflow (SF). The model considers only throughfall and, thus, is applicable only to stem distances $>1 \mathrm{~m}$. Output terms are the percolation out of the organic profile into the mineral topsoil (seepage, SP), evaporation from the litter surface (EV), flux into/out of the storage in the profile (ST) and water uptake by fine roots in the densily rooted organic profile (UP). Capillary rise from the mineral soil is neglected. To estimate EV, the Penman-Monteith equation was applied to the forest floor in a semi-empirical approach with net radiation, air and surface temperature, and air humidity recorded continuously. The surface conductance $g_{\mathrm{co}}$ is known to be fairly well related to the square root of the number of days since rainfall [5] and was estimated from gravimetric water loss determinations of humus nets being exposed in situ at the forest floor. The aerodynamic conductance for water vapour transfer above the forest floor $g_{\text {av }}$ was approximated from wind speed measurements above the canopy.

The model uses a mass balance approach and is based on empirically established relationships between rainfall amount, water retention of the humus material (wetting curves) and resulting percolation loss (see above). It requires daily throughfall and stand microclimatological data as well as the humus moisture content at a weekly interval as input data. After solving the water balance equation, the resulting term is taken as the water uptake by roots in the organic profile ( $\left.U P_{\text {org }}\right)$ :

$$
\mathrm{TF}+\mathrm{EV}+\mathrm{SP}+\mathrm{ST}+\mathrm{UP}_{\mathrm{org}}=0
$$

Table I gives an overview of the methods used to measure the fluxes directly; the empirical results served to validate the model.

In order to assess the relative contribution of root water uptake from a) the organic profile and $b$ ) the mineral soil, the results from the

Table I. Methods employed to measure or calculate the water turnover in the organic profile.

\begin{tabular}{ll}
\hline Water flux & \multicolumn{1}{c}{ Instrumentation } \\
\hline Canopy throughfall (TF) & $\begin{array}{l}16 \text { conventional rain gauges and } 1 \text { tipping bucket rain } \\
\text { gauge } \\
\text { a) gravimetric water loss determination of humus } \\
\text { material exposed in humus nets in situ, b) simplified } \\
\text { energy balance calculation at the forest floor using } \\
\text { 30-min means of net radiation, } \\
\text { air temperature and saturation deficit above } \\
\text { the litter surface }\end{array}$ \\
$\begin{array}{l}\text { Seepage out of the organic } \\
\text { profile (SP) }\end{array}$ & $\begin{array}{l}\text { a) direct registration by six ceramic suction plates at } \\
\text { potential, b) simulation with a humus percolation } \\
\text { model (see text) }\end{array}$ \\
Change in humus water storage (ST) & $\begin{array}{l}\text { weekly determination of the humus water content } \\
\text { by gravimetry } \\
\text { resulting flux after solving the humus water budget } \\
\text { equation }\end{array}$ \\
Root water uptake within &
\end{tabular}


forest floor water flux model were related to energy balance (Bowen ratio) measurements on a tower above the forest canopy. Whole stand evapotranspiration rates (ET) were derived from 30-min means of temperature and air humidity gradients above the canopy in the summer periods of 1991 and 1992 (Leuschner, unpublished data). On dry days, the calculated root water uptake rate in the organic profile (UP $\mathrm{Urg}_{\text {org }}$ ) was subtracted together with the litter evaporation rate (EV) from ET to estimate the water extraction by roots located in the mineral soil profile $\left(\mathrm{UP}_{\min }\right)$ and to assess the relative contribution of the forest floor to the stand water uptake

$$
\mathrm{UP}_{\min }=\mathrm{ET}-\mathrm{UP}_{\text {org }}-\mathrm{EV}
$$

\subsection{Fine root analysis}

Tree finest root biomass (diameter $<1 \mathrm{~mm}$ ) and the number of fine root tips were counted in $100 \mathrm{~cm}^{3}$ samples (ten replicates per horizon) taken in July/August 1993 in various horizons of the forest floor and the underlying mineral soil down to $60 \mathrm{~cm}$ deep. Sampling procedure and separation of biomass and necromass are described in detail in [3].

\section{RESULTS}

\subsection{Hydrologic characteristics of ectorganic material}

The water storage in the forest floor depends on 1) the water retention curve of the humus material, 2) the water conductivity of the material, and 3) the profile depth. The water content-soil water matric potential relationship (water retention curve) as determined in the laboratory by desorption gave a maximum water content $\theta_{\max }$ (= porosity) of about $90 \mathrm{vol} . \%$ for ectorganic material in the $\mathrm{O}_{\mathrm{F}}$ and $\mathrm{O}_{\mathrm{H}}$ layers of the study site. This is twice as high as for the quartzitic, medium-grained sand that underlies the forest floor (figure 1). More important, the organic material retained two to four times more water in the plant-available matric potential range $(-100 \mathrm{hPa}$ to $-1.5 \mathrm{MPa})$ than the sand. These properties favour root water uptake especially in the lower more decomposed layers of the organic profile

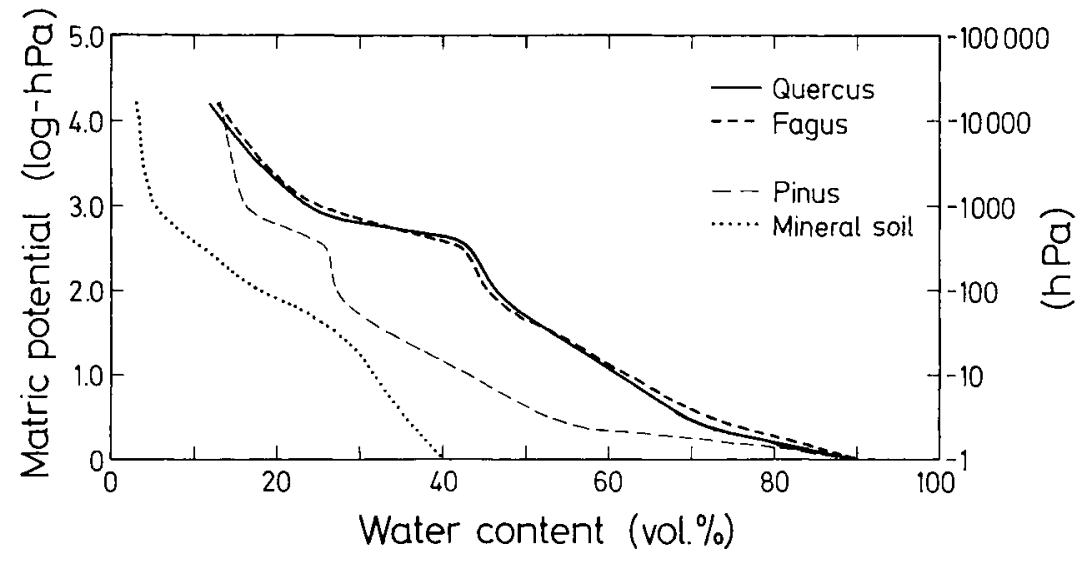

Figure 1. Water retention curves for ectorganic $\mathrm{O}_{\mathrm{FH}}$ material under beech, oak (site $\mathrm{OB}$ ) and pine (site BP3) trees as determined in the laboratory by desorption with hanging water columns (averages of five replicate samples each). The mineral soil characteristics refer to the sandy topsoil at $0-5 \mathrm{~cm}$ deep. 
and render the humus a suitable medium for root growth.

The water retention curve of humus material differs markedly between the three litter types (tree species) investigated: while humus derived from either beech or oak debris showed nearly identical desorption characteristics, gave pine humus retention curves that were markedly shifted to lower water contents in the physiologically important potential range (figure I). The amount of plant-available water, therefore, was by $20 \mathrm{vol}$ \% lower for pine humus than for oak or beech humus (table II). In contrast, humus of all three species retained much water in the non-root-extractable range (water < $-1.5 \mathrm{MPa}$ ) with no significant differences between beech, oak and pine.

Infiltration experiments with undisturbed forest floor sods gave empirical relationships between the amount of rainfall and the resulting seepage loss to the mineral soil (figure 2: lower part). These relationships are influenced by 1 ) the wetting characteristics of the humus material, i.e. the tendency of the matrix to absorb a part of the infiltrating water (figure 2 : upper part) and 2) the conductivity of the organic profile. Both properties are strongly dependent on the initial water content of the humus material. Quadratic equations were used to describe the water absorption following infiltration (wetting characteristics). They allow the calculation of the saturating water content $\theta_{\mathrm{s}}$ (i.e. the water content immediately after a saturating infiltration) and the water retention capacity $\theta_{\mathrm{r}}$ (i.e. the difference between saturating water content $\theta_{\mathrm{s}}$ and initial water content) under various water contents for the forest floor of the study site (table III).

For the beech forest floor, $\theta_{\mathrm{s}}$ is smaller by a factor of three for initially dry humus (10 $\mathrm{mm}$ water content in figure 2: curve no. 1, upper part) than for wet humus (31.5 mm content, curve no. 4). On the other hand, dry material (curve no.1, lower part) has a five times higher water retention capacity and, as a result, releases less seepage water to the mineral soil than wetter material. The saturating rainfall (throughfall) amount that is needed to reach $\theta_{\mathrm{s}}$ is much higher, however, for dry humus than for initially wet humus (table III). Thus, large seasonal fluctuations of the humus water content result in

Table II. Average depth and hydrologic characteristics of the organic profiles under oaks and beeches at site OB5 and under pines at site BP3 expressed as vol. \% water or $\mathrm{mm}$ water storage per profile (derived from water retention curves taken in the laboratory by desorption; $\theta_{\max }-$ porosity, i.e. all space filled with water; "non-root-extractable' - water held at matric potentials $<-1.5 \mathrm{MPa}$; 'plant-available' - water held between $-100 \mathrm{hPa}$ and $-1.5 \mathrm{MPa}$ ).

\begin{tabular}{lcccc}
\hline & & $\begin{array}{c}\text { Oak } \\
\text { (site OB5) }\end{array}$ & $\begin{array}{c}\text { Beech } \\
\text { (site OB5) }\end{array}$ & $\begin{array}{c}\text { Pine } \\
\text { (site BP3) }\end{array}$ \\
\hline Profile depth & $\mathrm{mm}$ & 104 & 80 & 85 \\
Saturated water & vol. \% & 90.5 & 90.0 & 91.6 \\
content $\theta_{\text {max }}$ & $\mathrm{mm}$ & 94.1 & 72.0 & 77.9 \\
Non-root-extractable & vol. \% & 12.1 & 13.3 & 13.2 \\
water & $\mathrm{mm}$ & 12.6 & 10.6 & 11.2 \\
Plant-available water & vol. \% & 34.4 & 32.2 & 14.0 \\
& $\mathrm{~mm}$ & 35.8 & 25.8 & 11.9 \\
\hline
\end{tabular}




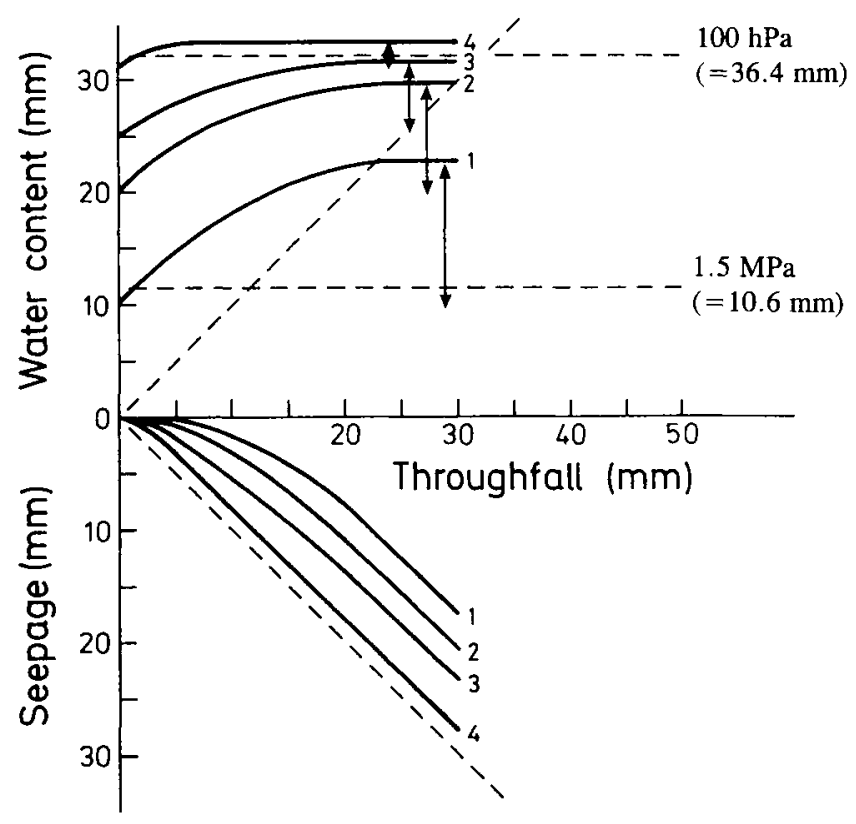

Figure 2. Relationship between rainfall (throughfall) height, water retention of the humus material (upper part of figure) and resulting percolation loss out of the forest floor (lower part of figure) as determined by infiltration experiments with beech forest floor sods in the laboratory. Curve nos 1-4 refer to different initial water contents of between 10 and $31.5 \mathrm{~mm}$ in the sods. Vertical arrows indicate the water retention capacity $\theta_{r}$ of the humus material (see text). Horizontal lines at 10.6 and $36.4 \mathrm{~mm}$ mark the water storage at $-1.5 \mathrm{MPa}$ and $-100 \mathrm{hPa}$, respectively, as determined by water retention curves (see figure $I$ ).

Table III. Parameters describing the relationship between rainfall (throughfall) and resulting percolation (seepage) for organic profile sods under beech at site OB5 (calculated from laboratory infiltration experiments.

\begin{tabular}{lcccccc}
\hline $\begin{array}{l}\text { Initial } \\
\text { water } \\
\text { content } \\
(\mathrm{mm})\end{array}$ & $a$ & $b$ & $c$ & $\begin{array}{c}\text { Water } \\
\text { retention } \\
\text { capacity } \theta_{\mathrm{r}} \\
(\mathrm{mm})\end{array}$ & $\begin{array}{c}\text { Saturating } \\
\text { water } \\
\text { content } \theta_{\mathrm{s}} \\
(\mathrm{mm})\end{array}$ & $\begin{array}{c}\text { Saturating } \\
\text { throughfall } \\
\text { amount } \\
(\mathrm{mm})\end{array}$ \\
\hline 10.0 & 0.0192 & 0.0107 & -0.1976 & 12.8 & 22.8 & c. 25 \\
20.0 & 0.0141 & 0.2807 & -0.5071 & 9.7 & 29.7 & c. 23 \\
25.0 & 0.0106 & 0.4707 & -0.2405 & 6.7 & 31.7 & c. 20 \\
31.5 & 0.0139 & 0.5289 & -0.5536 & 2.2 & 33.7 & c. 7 \\
\hline
\end{tabular}

Five replicates per initial water content stage. $a, b, c$, coefficients of equations $y=a x^{2}+b x+c$, where $y$ is the percolation and $x$ the throughfall (both in $\mathrm{mm}$ ). 
considerable temporal variations in both $\theta_{\mathrm{s}}$ and $\theta_{\mathrm{r}}$ and, consequently, in the amount of water that percolates to the mineral soil under a given infiltration rate.

\subsection{Humus moisture status}

The 8-10.5-cm-thick Mor profiles at the study site contain considerable water reserves not only during wet seasons but also during periods of summer drought. While winter values peaked at 50 vol. \% under oak trees, summer values ranged between 25 and 40 vol. \% in wet periods and reached minima of $18 \%$ in periods of drought (figure 3). Organic profiles under beech (with minima at 10 vol. \%) were somewhat drier than those under neighbouring oaks in the same stand. For comparison, pine humus, which consists mainly of the hydrophobic Pinus needles, reached summer minima $<5$ vol. \% (figure 3). As a consequence of these differences among the tree species, the average water storage in the organic profiles was

Lüneburger Heide (ВР 3+Ов 5) 1991

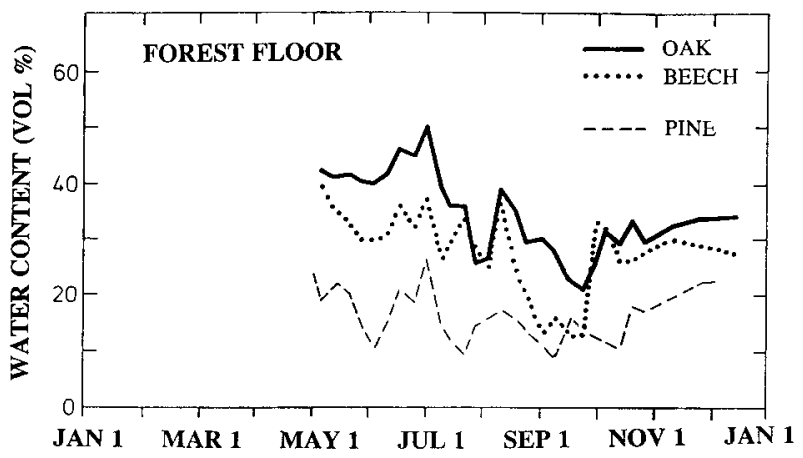

1992

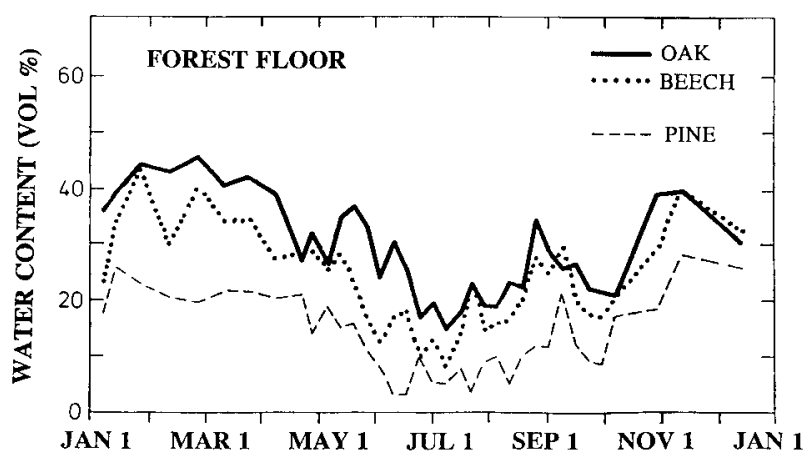

Figure 3. Seasonal evolution of measured water content in organic profiles under oak and beech trees (site OB5) or pine trees (site BP3) from May 1991 until December 1992 (averages of eight replicate samples each). 
more than three times larger under oak than under pine during summer (table IV). Maximum storage peaked at $45 \mathrm{~mm}$ under oak and beech in winter but reached only $27 \mathrm{~mm}$ under pine.

\subsection{Water turnover in the organic profile}

Figures 4 and 5 give the results of the water balance calculations for the forest

Table IV. Average water content (in vol. \%) and water storage (in $\mathrm{mm}$ ) in the organic profiles under beech and oak (site OB5) or pine (site BP3) in summer periods of 1991 and 1992.

\begin{tabular}{|c|c|c|c|c|}
\hline & \multicolumn{2}{|c|}{14 May-17 September 1991} & 18 May-20 September 1992 & $\begin{array}{l}1992 \\
(\mathrm{~mm})\end{array}$ \\
\hline Oak & 36.8 & 32.2 & 24.3 & 21.8 \\
\hline Beech & 28.1 & 16.4 & 17.8 & 12.5 \\
\hline Pine & 15.5 & 9.3 & 9.0 & 7.0 \\
\hline
\end{tabular}
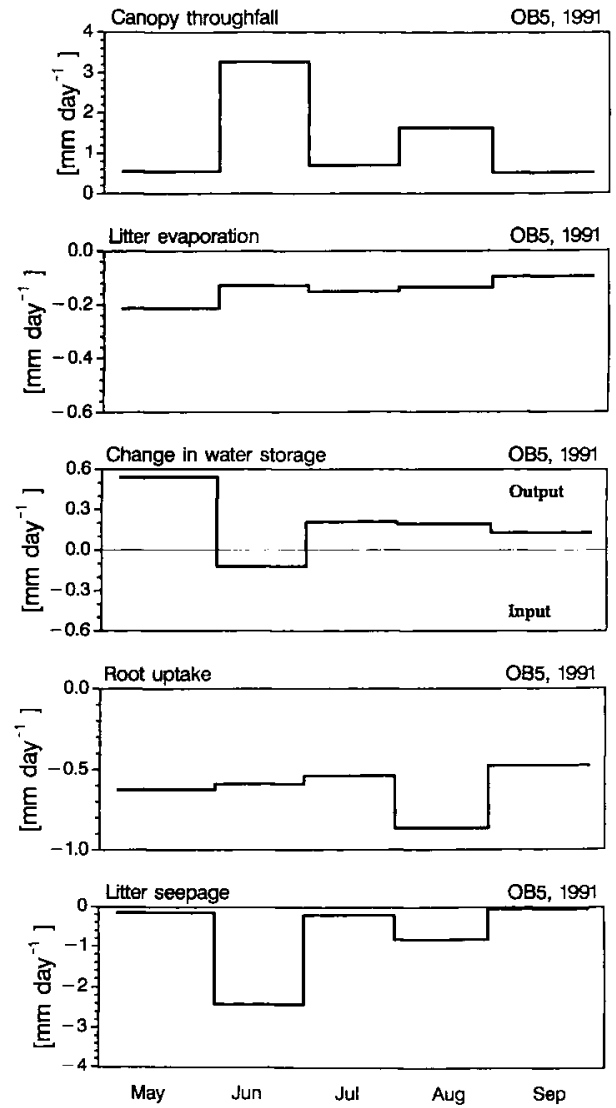

Figure 4. Monthly averages of the main hydrological fluxes in the organic profile of the oak-beech forest in summer 1991 (results from calculations with the forest floor water flux model). 

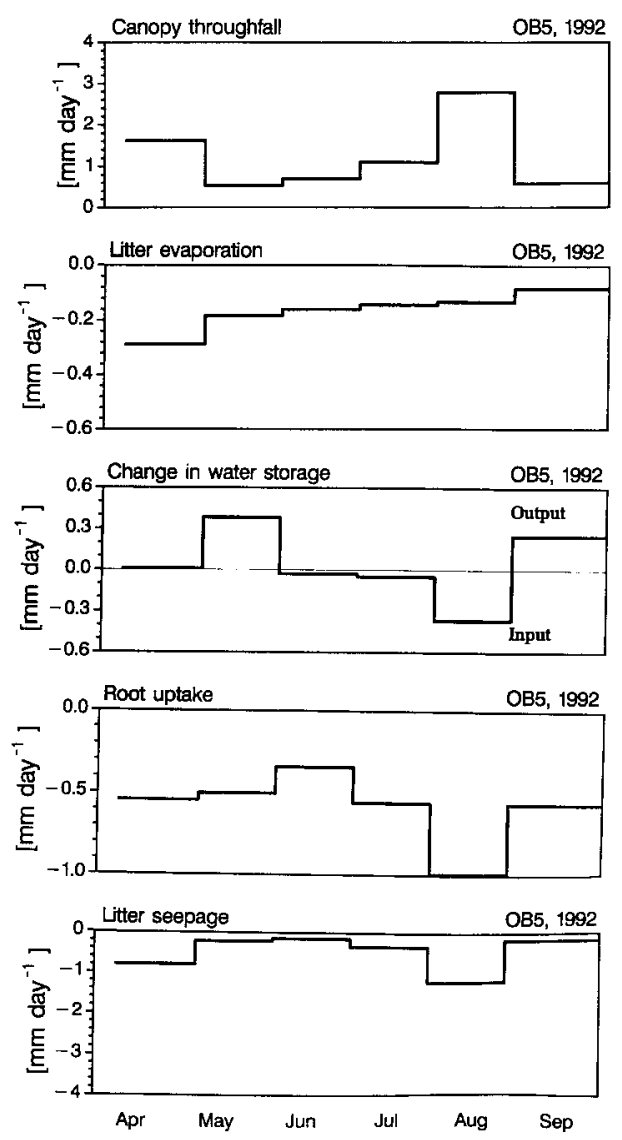

Figure 5. Monthly averages of the main hydrological fluxes in the organic profile of the oak-beech forest in summer 1992.

floor at the study site for the summer months (May-September) in 1991 and 1992. Based on daily canopy throughfall data, the forest floor water flux model gave daily rates of the water balance equation components, which are depicted as monthly averages in the graphs.

When comparing the canopy throughfall and the seepage rates, it becomes evident that, during summer, only wet months such as June 1991 and August 1992 yield a significant percolation through the organic profile and lead to an infiltration into the mineral soil. During the 1991 and
1992 summers, only $60 \%$ of the throughfall events resulted in a seepage out of the organic profile (Leuschner, unpublished data) and, more important, only $56 \%$ (1991) and $37 \%$ (1992) of the throughfall amount reached the mineral soil (see table $V$ ).

The model calculated remarkably constant water uptake rates of $0.5 \mathrm{~mm} \mathrm{~d}^{-1}$ for the tree roots in the organic profile during the summers in 1991 and 1992. Values peaked at 0.8 and $1.0 \mathrm{~mm} \mathrm{~d}^{-1}$ in the wet months August 1991 and August 1992 (figures 4 and 5). Even in the dry July 
Table V. Water fluxes in the organic profile at the site OB5 (mixed oak-beech forest) during summer 1991 and 1992 (in mm).

\begin{tabular}{lccccc}
\hline Period & TF & EV & SP & UP org & ST \\
\hline 7 May-25 September 1991 & 184 & 21 & 103 & 88 & -28 \\
$\begin{array}{l}\text { percent of input } \\
7 \text { May-1 October 1992 }\end{array}$ & 162 & 20 & 60 & 89 & -7 \\
percent of input & & $(12)$ & $(35)$ & $(53)$ & \\
\hline
\end{tabular}

$T F$, canopy throughfall; EV, litter evaporation; SP, seepage out of the organic profile; UP tree roots in the organic profile; ST, flux into or out of the storage in the organic profile. Numbers in parentheses express a water flux relative to the total water input into the organic profile (i.e. canopy throughfall + negative change in humus water storage).

1991 a high root uptake rate was calculated for the organic profile, which is consistent with the data on water reserves in the forest floor in this time (figure 6). Over the period May to September, nearly half of the water that infiltrated into the organic profile was extracted by the tree roots in this horizon. Given the small volume of the organic profile with a mean water storage during summer between $12.5 \mathrm{~mm}$ (for plots under beeches in 1992, see table IV) and $32.2 \mathrm{~mm}$ (for plots under oaks in 1991), root water uptake ( 88 and $89 \mathrm{~mm}$ in the summers 1991 and 1992, respectively) was very high. This indicates a rapid water turnover in the forest floor.

Litter evaporation as estimated from both energy balance calculations at the forest floor and gravimetric water loss determination showed maximum rates of $0.2 \mathrm{~mm} \mathrm{~d}^{-1}$ during the vegetation period and of $0.3 \mathrm{~mm} \mathrm{~d}^{-1}$ in the leafless season (e.g. April 1992).

\section{DISCUSSION}

Organic profiles can significantly contribute to the water supply of trees if a) the profile is thick enough to function as a water reservoir, b) litter decomposition has resulted in the forming of conspicious $\mathrm{O}_{\mathrm{F}}$ and $\mathrm{O}_{\mathrm{H}}$ humus layers with good water retention properties, and c) the type of litter supplied favours the storage of considerable amounts of water. These conditions are met in deciduous temperate forests on poor soils, which are characterized by an accumulation of ectorganic matter in the range of 25 to $30 \mathrm{~kg} \mathrm{C}$ in the forest floor [24]. In old-growth deciduous forests on intensively podzolized soils such as the studied oak-beech stand, even higher ectorganic carbon reserves in the range $35-50 \mathrm{~kg} \mathrm{C}$ have been measured [11]. These conditions are decisive if the organic profile is to play an important role in the water supply of forests.

\subsection{Different hydrologic characteristics of mineral soil and forest floor}

When compared to the sandy mineral soil, ectorganic $\mathrm{O}_{\mathrm{F}}$ and $\mathrm{O}_{\mathrm{H}}$ material of the oak-beech forest differs in its hydrologic properties in a three-fold manner:

1) The 'maximum water content' $\theta_{\max }$ (porosity) is more than twice as high owing to the very large pore volume and gives the forest floor an exceptionally high water storage capacity; it decreases, however, with proceeding litter decomposition downward in the profile. 


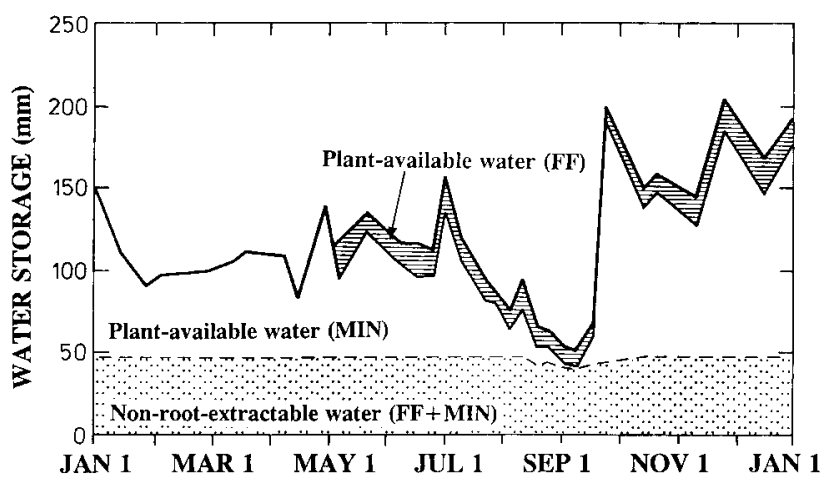

1992

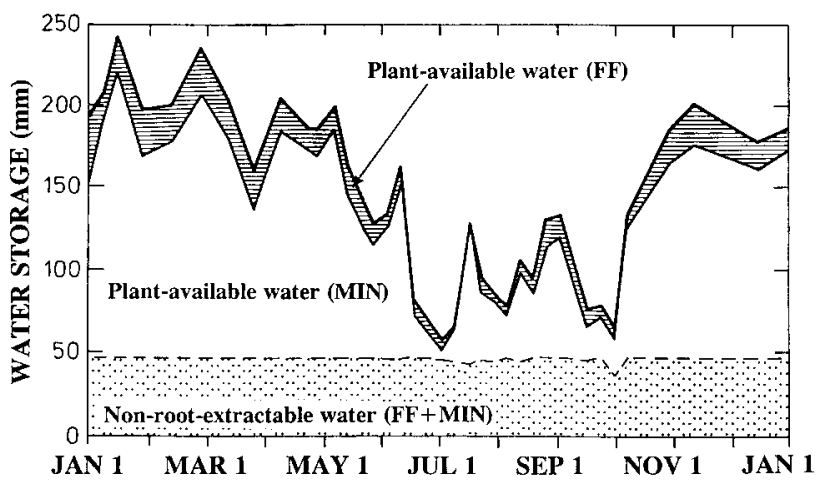

Figure 6. Water storage in the organic profile and the mineral soil $(0-70 \mathrm{~cm}$ depth $)$ of the oak-beech forest in 1991 and 1992 (no organic profile data exist for Jan-April 1991). "Nonplant-available water' refers to water held at $<-1.5 \mathrm{MPa}$, 'plant-available water' to water in the range $-100 \mathrm{hPa}$ to $-1.5 \mathrm{Mpa}$.

2) The 'saturated water content' $\theta_{s}$ is highly variable over time: it can increase by more than $50 \%$ when humus material changes from a low to a high material water content. Apparently, an increasing humus moisture content alters the texture, the surface properties and also the volume of the organic material with the consequence that basically wet material has a much larger saturated water content $\theta_{\mathrm{s}}$ than drier material. Thus, ectorganic material shows markedly different hydrologic properties over dry and wet periods of a season; this variability contrasts sharply with the much more stable hydrologic properties of the mineral soil material.

3) The 'water flow' through the organic profile (i.e. the percolation rate) is characterized by i) a high spatial and temporal heterogeneity (cf. [20]) with laminar flow being the exception, and ii) a strong dependence on the material water content and the hydrophobic surface properties of the organic debris. What makes an analysis 
of water flow even more difficult is the fact that water potential measurements in the organic material are more problematic than in the mineral soil, which limits the application of Darcy's equation [9]. Some researchers have tried to solve this problem by placing the tensiometers in the underlying mineral soil and refer to them (e.g. [20]). A more direct approach is the establishment of empirical relationships between rainfall amount, humus water content and resulting precolation rate by infiltration experiments as has been performed in this study. However, this procedure can introduce some artefacts and may not be suitable for a general forest floor water flux model since organic profiles with different texture and thickness are expected to behave differently. Furthermore, the experimental results from the laboratory require validation by field measurements as was achieved in this study by monitoring the water flow at the mineral soil/forest floor interface (see Methods, and Thamm and Widmoser [22]).

An important result of our infiltration experiments was the finding that, during summer, about half of the canopy through- fall is turned over in the organic profile via evaporation or root uptake and does not reach the mineral soil. Thus, during summer, a relatively dry forest floor more or less isolates the mineral soil profile lower down from the rainfall events. This is important for assessing the hydrological role of the forest floor in this stand, but also must have consequences for water flow models in forest ecosystems which, with very few exceptions, ignore the forest floor.

\subsection{Relative importance of the organic profile in the stand water balance}

How important is the forest floor in the Lüneburger Heide oak-beech forest for the water demand of the trees? Figure 6 contrasts the 'water storage' in the organic profile with the water reserves in the underlying mineral soil profile. During the summer months of 1991 and 1992, the forest floor contributed on average $27 \%$ (in the moderately dry summer 1991) and $14 \%$ (in the dry summer 1992) to the total soil water reserves (down to $70 \mathrm{~cm}$ deep, table VI).

Table VI. Average reserves of plant-available water $(-100 \mathrm{hPa}$ to $-1.5 \mathrm{MPa})$ and cumulative water extraction in summer periods of 1991 and 1992 for the organic profile and the mineral soil profile $(0-70 \mathrm{~cm}$ deep) at site OB5.

\begin{tabular}{|c|c|c|c|c|c|c|}
\hline & \multicolumn{3}{|c|}{1991} & \multicolumn{3}{|c|}{1992} \\
\hline & $\begin{array}{l}\text { Organic } \\
\text { profile }\end{array}$ & $\begin{array}{l}\text { Mineral } \\
\text { soil }\end{array}$ & Total & $\begin{array}{c}\text { Organic } \\
\text { profile }\end{array}$ & $\begin{array}{l}\text { Mineral } \\
\text { soil }\end{array}$ & Total \\
\hline $\begin{array}{l}\text { Average plant-available } \\
\text { water }(\mathrm{mm})^{\mathrm{a}}\end{array}$ & $\begin{array}{c}12.1 \\
(27 \%)\end{array}$ & 33.0 & 45.1 & $\begin{array}{c}8.2 \\
(14 \%)\end{array}$ & 52.1 & 60.3 \\
\hline $\begin{array}{l}\text { Cumulative water } \\
\text { extraction }(\mathrm{mm})^{\mathrm{b}}\end{array}$ & $\begin{array}{c}88.5 \\
(35 \%)\end{array}$ & 162.9 & 251.4 & $\begin{array}{c}87.8 \\
(28 \%)\end{array}$ & 223.4 & 311.2 \\
\hline $\begin{array}{l}\text { Estimated water } \\
\text { turnover rate }\end{array}$ & 7.3 & 4.9 & 5.6 & 10.7 & 4.3 & 5.2 \\
\hline
\end{tabular}

${ }^{a}$ Period 15 May-20 September; ${ }^{b}$ period 1 May-30 September; ${ }^{c}$ water extraction/plant-available water. Numbers in parentheses give the proportion of the organic profile in percent of the soil total. 
The organic profile plays an even more important role when its contribution to the stand 'water uptake' is considered: according to the calculations of the forest floor water flux model, about $37 \%$ of the water transpired by the stand from May to September 1991 must have been taken up by roots in the forest floor while the remaining $63 \%$ originated from the mineral soil (table VI). For the summer in 1992, a forest floor contribution of $28 \%$ was calculated. Thus, in this forest stand, the organic profile of only 8 to $10.5 \mathrm{~cm}$ deep represents an important source of water for consumption by the trees. This is linked to a rapid water turnover in the organic profile which apparently is much higher than in the mineral soil (table VI) and is supported by i) the very high fine root density, and ii) the favourable moisture status in the forest floor (see also table $I V)$. For stands with a thinner organic profile and/or with less favourable water retention characteristics (such as many conifer forests), only a small or even a negligible contribution of the forest floor to the root water uptake was found: for a Douglas fir stand in the Netherlands with a 5-cm-thick forest floor of poorly decomposed needles, Schaap [20] calculated that only $2.2 \%$ of the total root water uptake was derived from the forest floor.

\subsection{Water uptake and root distribution}

Superficial rooting is a typical attribute of trees on nutrient-poor acidic soils [14, 15]. Intensive studies on the fine root system of this stand ([3]; Hertel, unpublished data) showed that roughly $45 \%$ of the stand total of the finest root biomass (diameter $<1 \mathrm{~mm}$ ) is concentrated in the organic profile (table VII). The density of finest roots (expressed in $\mathrm{mg}$ biomass per $100 \mathrm{~cm}^{3}$ ), therefore, is three to four times higher in the organic $\mathrm{O}_{\mathrm{F}}$ and $\mathrm{O}_{\mathrm{H}}$ horizons than in any mineral horizon [12]. Even more striking is the fact that more than $90 \%$ of the living root tips of the total profile occurred in the organic horizons.

When the root distribution patterns are contrasted with the water extration rates as calculated for the summer (May to September) 1992, the following three conclusions on the functionality in water uptake of the tree root system can be drawn:

1) From the mineral soil to the organic profile, the soil-volume-related water extraction rate (in $\mathrm{cm}^{3}$ water per $\mathrm{cm}^{3}$ volume) increases in parallel with the density of finest roots. One could conclude that the more rapid turnover of the water reserves in the organic profile (see table $V I$ ) is mainly a result of the higher finest root density here (cf. [1]). However, alternative explanations are also possible: i) a better water availability in the forest floor (i.e. a larger soil-root potential gradient) could allow a higher specific water uptake rate of these roots; ii) a higher degree of branching and more fine root tips, as is typical for the organic profile root system, result in a higher specific surface of the forest floor finest roots, which could enable a higher water influx per root mass.

2) Since the concentration of fine root tips (and ectomycorrhizas, ECM) is 90 times higher in the organic profile than in the nutrient-poor mineral soil whereas the volume-related water extraction rate increases by a factor of three only, it is to be concluded that both tips and ECM contribute only marginally to the uptake of soil water in this stand. The key function of these organs is to be seen in the context of nutrient absorption [7].

3) Although we do not have information on the life span and the maintenance costs of finest roots in this stand, one can assume that, in the context of water uptake alone, the finest roots in the mineral soil should operate more economically than those in the organic profile: the amount 


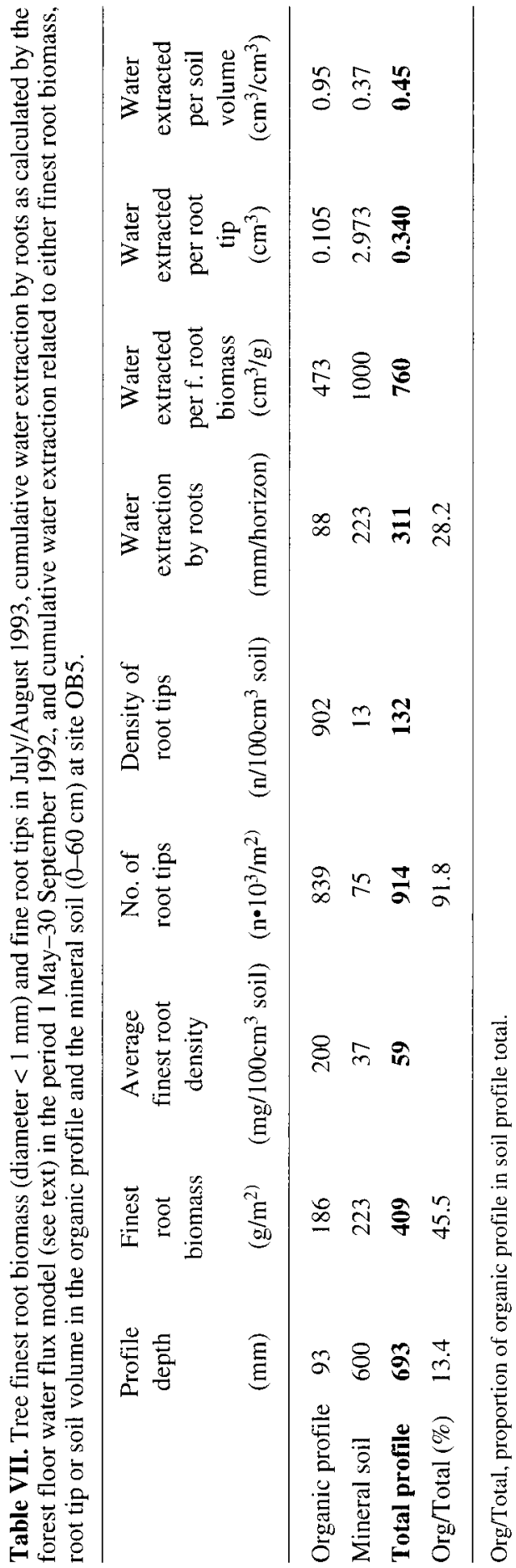


of water taken up in the summer 1992 per biomass of finest roots was more than twice as high in the mineral soil than in the organic profile. This has to be contrasted with the higher soil-volume-related water uptake which, in theory, should lead to a smaller extension of the root system and, thus, to reduced carbon costs of water acquisition.

The forest floor plays an important role in the hydrology of this forest not only through its contribution to the stand water demand: the comparably high humus water content is a basic requirement for a high microorganism activity and decomposition rate [23]. More important, the intensive nutrient uptake, which takes place in the forest floor, is also dependent on a favourable humus moisture status.

\section{ACKNOWLEDGEMENTS}

This research was supported by grants from the German Federal Ministry for Education, Science, Research and Technology (BMBF: project no. P.6.3.8., Stabilitätsbedingungen von Waldökosystemen, Forschungszentrum Waldökosysteme, Universität Göttingen) and from the Commission of the European Communities (contract no. EV4V-0148-C(BA)). Much of the field work was conducted by Gaby Görlitz, Andrea Dageförde, Dietrich Hertel and Katharina Backes which is gratefully acknowledged.

\section{REFERENCES}

[1] Benecke P., Der Wasserumsatz eines Buchenund eines Fichtenwaldökosystems im Hochsolling, Schr Forstl Fak Univ Göttingen 77,1984

[2] Blow F.E., Quantity and hydrologic characteristics of litter under upland oak forests in Eastern Tennessee, J. For. 53 (1955) 190-195.

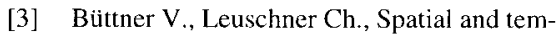
poral patterns of fine root abundance in a mixed oak-beech stand, For. Ecol. Manag. 70) (1994) 11-21.

[4] Chrosciewicz Z., Prediction of forest-floor moisture content under diverse Jack pine canopy conditions, Can J. For. Res. 19 (1989) 1483-1487.

[5] Denmead O.T., Plant physiological methods for studying evapotranspiration: problems of telling the forest from the trees, Agric. Water Manag. 8 (1984) 167-189.

[6] Ellenberg H., Mayer R., Schauermann J. (Eds.) Ergebnisse des Solling-Projekts 1966-1986, Ulmer, Stuttgart, 1986.

[7] Harley J.L., Smith S.E., Mycorrhizal Symbiosis, Academic Press, London, 1983.

[8] Helvey J.D., Patric J.H., Canopy and litter interception of rainfall by hardwoods of the eastern United States, Water Resources Res. 1 (1965) 193-206.

[9] Hölzer R., Wasserhaushaltsuntersuchungen der Streu- und obersten Bodenschicht eines Fichtenbestandes unter Verwendung von Modellrechnungen, Beiträge zur Hydrologie (Kirchzarten), Sonderheft 4 (1982) 117-144.

[10] Klinka K., Green R.N., Trowbridge R.L., Towards a taxonomic classification of humus forms, For. Sci. Monogr. 29, 1993.

[11] Leuschner Ch., Rode M.W., Danner E., Lübbe K., Clauss C., Margraf S., Runge M., Soil profile alteration and humus accumulation during heathland-forest succession in NW Germany, Scripta Geobotanica (Göttingen) 21 (1993) 73-84.

[12] Leuschner C., Changes in forest ecosystem function with succession in the Lüneburger Heide, in: Lenz R., Hantschel R., Tenhunen, J.D. (Eds.), Ecosystem Properties and Landscape Function in Central Europe, Processes in Managed Ecosystems. Springer, Berlin, 1998.

[13] Likens G.E., Bormann F.H., Biogeochemistry of a Forested Ecosystem, 2nd ed., Springer, New York, 1995.

[14] Meyer F.H., Feinwurzelverteilung bei Waldbäumen in Abhängigkeit vom Substrat, Forstarchiv 38 (1967) 286-290.

[15] Persson H., Spatial distribution of fine-root growth, mortality and decomposition in a young Scots pine stand in Central Sweden, Oikos 34 (1980) 77-87.

[16] Plamondon P.A., Black T.A., Goodell B.C., The role of hydrologic properties of the forest floor in watershed hydrology, in: Csallany S.C., McLaughlin T.G., Striffler W.D. (Eds.), National Symposium on Watersheds in Transition, Proceedings Series 14, American Water Resources Association, Urbana, Illinois, 1972, pp. 341-348.

[17] Proctor J. (Ed., 1989), Mineral Nutrients in Tropical Forest and Savanna, Blackwell, Oxford.

[18] Rode M.W., Above-ground nutrient cycling and forest development on poor sandy soil, Plant and Soil 168-169 (1995) 337--343. 
[19] Runge M., Physiology and ecology of nitrogen nutrition, in: Lange O.L., Nobel P.S., Osmond C.B., Ziegler H. (Eds.), Encyclopedia of Plant Physiology, NS vol 12C, Springer, Berlin Heidelberg New York, 1983, pp. 163-200.

[20] Schaap M.G., The role of soil organic matter in the hydrology of forests on dry sandy soils, Ph.D. thesis, University of Amsterdam.

[21] Strong W.L., LaRoi G.H., Rooting depths and successional development of selected boreal forest communities, Can J. For. Res. 13 (1983) 577-588.

[22] Thamm F., Widmoser P., Zur hydrologischen Bedeutung der organischen Auflage im Wald: Untersuchungsmethoden und erste Ergeb- nisse, Z Pflanzenernähr Bodenk 158 (1995) 287-292.

[23] Tietema A., Lenting E., Warmerdam B., Riemer L., Abiotic factors regulating nitrogen transformations in the organic layer of acid forest soils: moisture and $\mathrm{pH}$, Plant and Soil 147 (1992) 69-78.

[24] Ulrich B., Puhe J., Auswirkungen der zukünftigen Klimaveränderung auf mitteleuropäische Waldökosysteme und deren Rückkopplungen auf den Treibhauseffekt. Studienbericht für die Enquete-Kommission «Schutz der Erdatmosphäre» des Deutschen Bundestages, Göttingen, 1993.

[25] Walsh R.P.D., Voight P.J., Vegetation litter: an understimated variable in hydrology and geomorphology, J. Biogeo. 4 (1977) 253-274. 